\title{
A civil szervezetek szerepe a környezeti felelösség érvényesítésében
}

\author{
The Role of Non-Governmental Organisations in the Enforcement \\ of Environmental Liability
}

\begin{abstract}
ABSZTRAKT
A társadalmi részvétel lényeges eleme a környezeti problémák kezelésének. Az Aarhusi Egyezmény és az uniós jog is elöírja, hogy a polgárok és a környezetvédő civil szervezetek számára garantálni kell az igazságszolgáltatáshoz való hozzáférést, amely magában foglalja a környezetvédő civil szervezetek és a környezeti jog megsértése által közvetlenül érintett egyének kereshetőségi jogának a biztosítását. A környezeti felelősségről szóló irányelv értelmében a környezeti károk által kedvezőtlenül érintett személyek jogosultak arra, hogy az illetékes hatóságoktól intézkedés megtételét kérjék. A környezetvédelmi szabályok végrehajtása terén azonban jelentős nehézségek tapasztalhatók, amelyekkel a környezetvédő civil szervezetek is szembesülnek az ahhoz szükséges kereshetőségi jog megszerzése során, hogy a környezeti ügyekben jogi eljárásokat indíthassanak.
\end{abstract}

Kulcsszavak: civil szervezetek, társadalmi részvétel, Aarhusi Egyezmény, környezeti felelősség, ügyféli jogállás

\begin{abstract}
Public participation is an essential part of the mechanism of dealing with environmental problems. Both the Aarhus Convention and Union law stipulate that citizens and environmental NGOs should be guaranteed access to justice that includes providing legal standing for environmental NGOs individuals and directly affected by a breach of environmental law. In accordance with the Environmental Liability Directive, persons adversely affected by environmental damage are entitled to ask the competent authorities to take action. However, there are major challenges to the implementation of environmental legislation, faced by environmental NGOs in obtaining standing to bring legal challenges on environmental issues.
\end{abstract}

Keywords: environmental NGOs, public participation, Aarhus Convention, environmental liability, legal status of interested parties

A környezeti kockázatok visszaszorítása, illetve a szennyező fizet elvén alapuló környezeti felelösség érvényesítése alapvetően állami feladat, amit gyakran csak határokon átnyúló jelleggel, nemzetközi együttmúködés keretében lehet hatékonyan megvalósítani. A felelősség kérdése természetesen a környezethasználókat érinti elsősorban, több évtizedes tapasztalatok bizonyítják azonban, hogy a környezethasználók önkéntes jogkövetése, illetve a hatóságok fellépése együttesen sem

\footnotetext{
* Dr. Pánovics Attila egyetemi adjunktus, Pécsi Tudományegyetem Állam- és Jogtudományi Kar Nemzetköziés Európajogi Tanszék; e-mail: panovics.attila@ajk.pte.hu.
} 
elegendő a környezeti felelősség következetes érvényesítéséhez, illetve rosszabb esetekben a bekövetkezett környezeti károk elhárításához.

Az egyértelmű és pontos jogszabályi előírások hiánya természetesen önmagában is akadályozza a szennyező fizet elv minél teljesebb körü érvényesülését, még jellemzőbbek a végrehajtás terén tapasztalható problémák. Utóbbiak orvoslásának elöremutató és költséghatékony eszköze a társadalmi részvétel elvének az érvényesítése: a nyilvánosság bevonása, az egyének és különösen a környezetvédő civil szervezetek aktív szerepvállalásának a bátorítása. Ennek jogszabályi hátterét nemzetközi és uniós elöírások egyaránt garantálják, hazai viszonyok között azonban messze nincsenek még kiaknázva a benne rejlő lehetőségek. Megértés, bizalom és partnerség hiányában a társadalom részvételét lehetővé tevő rendelkezések nem képesek biztosítani mindazokat az elönyöket, amelyek többek között a környezeti felelősségről szóló szabályok végrehajtása terén is jelentősen csökkenteni tudnák a meglévő hiányosságokat.

\section{Civil közösségek és környezetvédelmi mozgalmak}

Egy (poszt)modern társadalomban a civil közösségek ideális keretet kínálnak az individualizált egyéneknek, ${ }^{1}$ hogy társadalmi aktivitásukat kifejthessék oly módon, hogy közben az autonómiájukat is megörzik. ${ }^{2}$ Ezért általánosságban is különösen fontos, hogy a civil szervezetek függetlenek legyenek az államtól. Ha az állam rátelepszik a civil szervezetekre, akkor nemcsak a függetlenségük veszik el, hanem az önkéntesség és a rugalmasság is, és megszünik vagy erősen csökken a tagok autonómiája. A független civil közösségek müködése ezért tulajdonképpen az állam és a társadalom egyfajta elválasztását is jelenti. ${ }^{3}$ Függetlenség vagy tevékenység szélsőséges esetben így is megfogalmazható a helyzet. ${ }^{4}$

A civil szektor rendkívül heterogén, vannak köztük informális és formális jellegü, a helyitől egészen a nemzetközi szintig aktívan tevékenykedő, a legkülönfélébb területekkel foglalkozó, kompromisszum- és konfliktusalapú szervezetek egyaránt. A klasszikus civil szervezetek (egyesületek, alapítványok) leggyakrabban közös értékek mentén szerveződnek, amelyek közé sorolható a tágabb értelemben vett környezetvédelem is. A közérdeket saját külön érdek nélkül is próbálják érvényesíteni, ami voltaképpen a közhatalom müködésének bírálata. ${ }^{5}$

A környezetvédő civil szervezetek nevelési-oktatási, kezdeményező, ellenőrző, közremüködő stb. tevékenységének számos eszköze és megnyilvánulási formája ismert. ${ }^{6}$ Tevékenységük azonban sajátos abból a szempontból, hogy egy mindenkit -

${ }^{1}$ A civil közösségek megfelelő működéséhez valójában az individualizmus és a kollektivizmus megfelelő arányára van szükség.

2 KöRMENDY Lajos: A közösség nélküli ember. Ad Librum, Budapest, 2020, 332.

${ }^{3}$ KÖRMENDY: i. m., 201.

${ }^{4}$ Sebestyén István: Civil dilemmák - Kihívások és alternatívák a civil szektorban. Civitalis Egyesület, Budapest, 2005, 66.

${ }^{5}$ Sótyom László: DOCUMENTA - Polgári jog. HVG-ORAC, 2019, 805.

${ }^{6}$ ÁDÁm Antal: A társadalmi szervezetek szerepe a környezetvédelemben. Állam és Igazgatás, 1979/7, 647. 
méghozzá a jelen és jövő nemzedékeket is - egyre közvetlenebbül érintő, valójában rendszerszintü probléma(halmaz) megoldását keresik, és különböző mértékben, de egy fenntarthatóbb állapot elérését szeretnék elérni. Ez a közös küldetéstudat teszi lehetővé, hogy a zöldek a helyitől a nemzetközi szintig együttmüködéseket alakítsanak ki, illetve a világ minden részén jelen lévő hálózatokba tömörüljenek.

A környezetvédelmi mozgalmak elvi szinten a közpolitika befolyásolására vállalkoznak a mögöttük álló széles társadalmi - jellemzően anyagilag függetlenebb, a meggyőződéséért némi áldozatra is kész, középosztálybeli - bázis alapján. Magyarországon azonban nemcsak ennek a rétegnek a kialakulása várat magára, ${ }^{7}$ hanem hiányzik a társadalom szocializációjából a civil szerveződés élménye, illetve annak tudatosítása is, hogy a civil szervezetek mennyire fontos és hasznos tevékenységet végeznek. Pedig a rendszerváltozást megelőző, átmeneti időszakban számos civil szervezet alakult, illetve indult újra, továbbá erős lökést jelentett a hazai környezetvédelmi mozgalom megerősödéséhez a bős-nagymarosi vízlépcsőrendszer elleni tiltakozás, amelynek köszönhetően az 1980-as évek közepén alakult Duna Kör nemzetközi szinten is komoly tekintélyre tett szert. ${ }^{8}$ A lakosság gyenge környezeti tudatossága, valamint a civil szférát támogató, tudatos és széles középosztály hiánya azonban nagyban hozzájárult ahhoz, hogy a környezetvédő civil szervezetek számbeli növekedése ellenére sem a tömegbázisuk, sem a közpolitikai döntésekre gyakorolt befolyásuk nem tudott megerősödni. A környezetvédelem társadalmi támogatottsága egyértelmüen visszaesett, és a környezeti konfliktusok száma is csökkent. $^{9}$

\section{Társadalmi részvétel környezeti ügyekben}

Az ún. ökoszisztéma-szolgáltatások mindenki számára hasznosak és elengedhetetlenek, ezért azok fenntartása, müködőképességük megőrzése a társadalom közös érdeke és felelőssége. Igen szellemes az a megfogalmazás, amely szerint az emberek nagyon sok olyan kérdésben hoznak döntést, amelyekhez nem igazán értenek, a képviselőkre történő szavazástól az orvosválasztásig az életünket, egészségünket alapvetően befolyásoló ügyekről van szó. Miért pont a környezetvédelmi kérdésekbe ne lenne beleszólásunk? ${ }^{10}$

Nem vitatható, hogy az öko-logikus gondolkodás érvényesülésének előfeltétele a személyes részvétel a döntés-előkészítés és a döntéshozatal folyamataiban, ${ }^{11}$ ami leghatékonyabban lokális szinten valósulhat meg. A környezetvédő civil aktivitás

\footnotetext{
${ }^{7}$ RAdÁcsı László: Részvétel és fenntartható fejlődés. In: Bulla Miklós-Tamás Pál (szerk.): Fenntartható fejlődés Magyarországon. Jövőképek és forgatókönyvek. Új Mandátum, Budapest, 2006, 260.

${ }^{8}$ SÁmsondı Kıss György: A Duna mégis összeköt - Egy kormánybiztos vallomásai. Kairosz, Budapest, 2019, 167.

${ }^{9}$ SzIRMAI Viktória: Környezeti érdekérvényesítés konfliktusai. In: Bulla Miklós-Tamás Pál (szerk.): Magyarország környezeti jövőképe. Országos Környezetvédelmi Tanács-MTA Szociológiai Kutatóintézet, $2003,285$.

${ }^{10}$ CSUTORA Mária-KeREKES Sándor: A környezetbarát vállalatirányítás eszközei. KJK-KERSZÖV, Budapest, 2004, 173.

11 LÁNYI András: Létezik-e? (esszék). Hanga - Új Mandátum, Budapest, 2003, 30.
} 
ezért jellemzően alulról szerveződő (grassroots) mozgalom, hiszen az érezhető és életminőséget rontó környezeti hatásokat az állampolgárok általában a lakóhelyükön, a közvetlen környezetükben érzékelik közvetlenül.

A társadalmi részvételnek környezeti ügyekben számos elönye ismert, és bár megemlíthetők esetleges hátrányai is, elöbbiek azonban összességükben jelentősen meghaladják az utóbbiakat. ${ }^{12}$ Témánk szempontjából az előnyök közül feltétlenül kiemelendő, hogy a helyi lakosok eljuttathatják a rendelkezésükre álló információkat a hivatalos szervek részére, és azok meghosszabbított karjaként - pontosabban a szemeként és füleként ${ }^{13}$ - jelzik az általuk észlelt jogsértéseket. A széles körü és hatékony társadalmi részvétel másrészt bizonyítottan csökkenteni képes a megalkotott környezetvédelmi szabályok alkalmazásának hiányosságait, ami mind nemzeti, mind uniós szinten állandó kihívást jelent.

A környezethasználat által kijelölt hatásterületen lévő környezeti teherviselök között jelentős különbségek lehetnek a rendelkezésre álló információk, tudás, szakmai felkészültség és eszközök tekintetében. Ezért is különösen fontos a formalizált civil szervezetek szerepe, mert a rajtuk keresztül történő fellépés olcsóbbá és hatékonyabbá is teszi a jogérvényesítést, mennyiségi és minőségi szempontból is megkönnyítve a hivatalos szervek munkáját. Idö-, energia- és költségcsökkentő hatása is van ugyanis, ha az egyes személyek helyett - akik egyénileg talán nem is kezdeményeznének eljárásokat - nagyobb szakértelemmel felruházott civil szervezetek lépnek fel a környezeti érdekek érvényesítése érdekében.

A környezetvédelmi tárgyú jogszabályok végrehajtási deficitje azt mutatja, hogy önmagában az állami szervek (elsősorban a hatóságok) fellépése nem biztosít elegendő garanciát a környezeti érdekek hatékony érvényesülésére. ${ }^{14}$ Annak ellenére, hogy a környezet és a természet védelme alapvetően állami feladat, az elmúlt évtizedekben nem sikerült széles körü, látványos eredményeket elérni a környezet állapotát tekintve..$^{15}$ Márpedig abból kiindulva, hogy a társadalmi részvétel elve egy eljárási érdeket is tartalmaz, ennek értelmében az érintettek joggal várhatják el, hogy bevonják az őket érintő környezeti döntések meghozatalába. ${ }^{16}$ Nem véletlenül indult meg az 1990-es évektöl egy látványos jogfejlödés, ami a környezeti demokrácia erősödésével is szoros összefüggésben áll, melynek legismertebb példája az 1998-ban aláírt Aarhusi Egyezmény.

\footnotetext{
${ }^{12}$ DelLINGER, Marianne: Ten Years of the Aarhus Convention: How Procedural Democracy is Paving the Way for Substantive Change in National and International Environmental Law. Colorado Journal of International Environmental Law \& Policy, 2012/2, 317.

${ }^{13}$ Lásd például Illinois állam igazságügyi miniszterének honlapját: https://illinoisattorneygeneral.gov/environment/envdivision.html (2020. 06. 26.).

${ }^{14}$ VANHALA, Lisa: Shaping the Structure of Legal Opportunities: Environmental NGOs Bringing International Environmental Procedural Rights Back Home, Law \& Policy, 2018/1, 110-127. (https://doi.org/10.1111/ lapo.12093); GIESEKE, Ulrich: The Aarhus Convention in Practice: Challenges and Perspectives for German Environmental Authorities. Journal for European Environmental \& Planning Law, 2019/4, 372-385. (https:// doi.org/10.1163/18760104-01604004).

${ }^{15}$ The European environment - state and outlook 2020, Knowledge for transition to a sustainable Europe. European Environment Agency, 2019, 9.

${ }^{16}$ Ez nem összekeverendő az eljáráshoz füződő érdekkel, mint a perképesség feltételével.
} 


\section{Az Aarhusi Egyezmény}

1992-ben, az első Riói Konferencián elfogadott Nyilatkozat 1. számú elve jelentette a legfontosabb kiindulópontját az Európa Környezetéért folyamat 4. miniszteri konferenciáján, a dániai Aarhusban elfogadott nemzetközi szerződésnek, ${ }^{17}$ amely a nyilvánosság lehető legszélesebb körü részvételét szorgalmazza. ${ }^{18}$ Annak ellenére, hogy az Aarhusi Egyezmény kifejezetten regionális (páneurópai ${ }^{19}$ ) jellegú, mintául szolgált a 2018-ban elfogadott Escazú Megállapodáshoz Latin-Amerikában. ${ }^{20}$

Az Egyezmény - amelynek kidolgozásában a környezetvédő szervezetek aktív és konstruktív módon vettek részt ${ }^{21}-a$ társadalmi részvétel három, alapvető fontosságú területével kapcsolatban garantálja a környezeti jogokat: 1. környezeti információkhoz való hozzáférés, 2. a környezettel kapcsolatos döntések meghozatalában való részvétel, 3 . igazságszolgáltatáshoz való hozzáférés környezeti ügyekben. Ezek közül egyértelműen az igazságszolgáltatáshoz való hozzáférés tekinthető a legritkábban alkalmazott, illetve a legtöbb problémát okozó, mégis a legnagyobb súllyal rendelkező eszköznek. Egyrészt szorosan kötődik a másik két eljárási jogosítványhoz, hiszen mind a környezeti információkhoz való hozzáférés, mind a különféle döntéshozatali eljárásokban való részvétel jogának elutasítása vagy korlátozása esetén rendelkezésre kell állnia megfelelő jogorvoslati lehetőségnek. ${ }^{22}$ Az igazságszolgáltatás hatékonysága másrészt azt is megköveteli, hogy az igazságszolgáltatáshoz való hozzáférés jogát csak olyan személyek gyakorolják, akiket az állítólagos jogsértés valamilyen módon érint.

Az Aarhusi Egyezmény megalkotói ezért a szerződő felekre kívánták hagyni annak meghatározását, hogy az igazságszolgáltatáshoz való hozzáféréshez milyen követelményeket kell teljesíteniük a nyilvánosság tagjainak. ${ }^{23} \mathrm{~A}$ tagállamok mozgásterét ugyanakkor korlátozza az, hogy az érintett nyilvánosságnak az igazságszolgáltatáshoz való hozzáférését széles körben kell biztosítani. ${ }^{24}$ Sőt, az Aarhusi Egyezmény 3. cikkének (5) bekezdése azt is lehetővé teszi, hogy a Felek olyan intézkedéseket fogadjanak el, amelyek az Egyezményben meghatározottaknál szélesebb körü jogokat biztosítanak.

Ami a civil szervezetek lehetőségeit illeti, az Aarhusi Egyezmény (és ez alapján az EU módosított Khv. irányelve ${ }^{25}$ a környezetvédelmi szervezetek esetében létre-

${ }^{17}$ Magyarországon kihirdette a 2001. évi LXXXI. törvény.

${ }^{18}$ Lásd Bobek fötanácsnok indítványát a C-826/18. sz., Stichting Varkens in Nood és társai ügyben (EU:C:2020:514, 74. pont).

${ }^{19}$ Az ENSZ Európai Gazdasági Bizottságának (EGB) jelenleg 56 tagja van, ebből 46 részese az Aarhusi Egyezménynek, beleértve az Európai Unió valamennyi tagállamát.

${ }^{20}$ BöGös Fruzsina: Aarhustól Escazúig: a környezeti jogok tengeren innen és túl. Közjogi Szemle, 2019/2, 15.

${ }^{21}$ Lásd az ENSZ Gazdasági és Szociális Tanácsának jelentését: https://www.unece.org/fileadmin/DAM/env/ documents/1996/cep/ac.3/cep.ac.3.2.e.pdf (2020. 06. 21.).

${ }^{22}$ PÁnovics Attila: Az Aarhusi Egyezmény és az Európai Unió. IDResearch/Publikon, Pécs, 2015, 32.

${ }^{23}$ Report on the seventh meeting. Economic Commission For Europe, Meeting of the Parties to the Convention on Access to Information, Public Participation in Decision-making and Access to Justice in Environmental Matters, Compliance Committee, 14 March 2005. ECE/MP.PP/2005/2/Add.3.

${ }^{24}$ A C-570/13 sz. Karoline Gruber kontra Unabhängiger Verwaltungssenat für Kärnten és társai ügyben 2015. április 16-án hozott ítélet, 39. pont (EU:C:2015:231).

25 Jelenleg az Európai Parlament és a Tanács 2011. december 13-i 2011/92/EU irányelve az egyes köz- és magánprojektek környezetre gyakorolt hatásainak vizsgálatáról (HL L 26, 28/1/2012, 1-21.). 
hozta az actio popularis egy formáját, pontosabban az a döntés született, hogy egy „józan és pragmatikus kompromisszum" eredményeként egy köztes megoldást alkalmaznak, megerősítve a környezetvédő szervezetek szerepét. ${ }^{26} \mathrm{Az}$ Egyezmény 2. cikkének (5) bekezdése alapján a környezetvédelmi szervezetek minden esetben az érintett nyilvánosság részének tekintendők, és az adott ügyben kellő érdekeltséggel rendelkezőnek minősülnek. Ezek a szervezetek tehát mindig az érintett nyilvánosság tagjainak minősülnek, amennyiben megfelelnek a nemzeti jog szerinti követelményeknek, ${ }^{27}$ és ennek köszönhetöen gyakorlatilag automatikusan megilleti öket a bírósághoz fordulás joga. ${ }^{28}$

\section{A magánszemélyek szerepe a környezeti felelösségröl szóló irányelvben}

Az Aarhusi Egyezmény aláírásától kezdve az Európai Unió (akkoriban még mint Európai Közösség) is igyekezett összhangba hozni a meglévő rendelkezéseit a nemzetközi szerződésből fakadó kötelezettségekkel. Ennek részeként két irányelv is elfogadásra került, ${ }^{29}$ kiegészítve olyan horizontális eszközökkel, mint a környezeti felelősségröl szóló irányelv, ${ }^{30}$ melynek elfogadását megelőzően a tagállami szintű szabályozások mind a védelem tárgyát, mind a felelősségi kritériumokat tekintve nagy eltéréseket mutattak az Európai Közösségen belül. Az EU környezeti szabályai között korábban mindössze egyetlen irányelv ${ }^{31}$ tartalmazott ezzel kapcsolatos rendelkezéseket, illetve figyelmen kívül hagyták a határokon átnyúló hatásokból származó kockázatokat is. ${ }^{32}$

Hosszú elökészítést követöen ${ }^{33}$ végül olyan minimumkövetelmények lefektetésére került sor, amelyek középpontjában a gazdasági szereplök (economic operators) pénzügyi felelőssége áll, amennyiben az irányelv értelmében, az emberi egészség-

${ }^{26}$ Lásd Sharpston fötanácsnok indítványát a C-664/15. sz., Protect Natur, Arten und Landschaftsschutz Umweltorganisation ügyben (EU:C:2017:760, 81. pont).

${ }^{27}$ The Aarhus Convention, An Implementation Guide. United Nations Economic Commission for Europe, Second edition, 2014, 194.

${ }^{28}$ Lásd Sharpston fötanácsnok indítványát a C-263/08. sz., DjurgårdenLilla Värtans Miljöskyddsförening ügyben (EU:C:2009:421, 43. pont).

${ }^{29}$ Az Európai Parlament és a Tanács 2003/4/EK irányelve (2003. január 28.) a környezeti információkhoz való nyilvános hozzáférésröl és a 90/313/EGK irányelv hatályon kívül helyezéséröl (HL L 41, 14/2/2003, 26-32.), illetve az Európai Parlament és a Tanács 2003/35/EK irányelve (2003. május 26.) a környezettel kapcsolatos egyes tervek és programok kidolgozásánál a nyilvánosság részvételéröl, valamint a nyilvánosság részvétele és az igazságszolgáltatáshoz való jog tekintetében a 85/337/EGK és a 96/61/EK tanácsi irányelv módosításáról (HL L 156, 25/6/2003, 17-25.).

${ }^{30}$ Az Európai Parlament és a Tanács 2004/35/EK irányelve (2004. április 21.) a környezeti károk megelőzése és felszámolása tekintetében a környezeti felelősségröl (HL L 143, 30/4/2004, 56-75.).

${ }^{31}$ Az Európai Parlament és a Tanács 2013/30/EU irányelve (2013. június 12.) a tengeri olaj- és gázipari tevékenységek biztonságáról (HL L 178, 28/6/2013, 66-106.).

32 Proposal for a Directive of the European Parliament and of the Council on the protection of persons reporting on breaches of Union law, COM(2018) 218 final, 23/4/2018.

$118{ }^{33}$ Pozzo, Barbara: Liability for Environmental Harm in Europe: Towards a Harmonised Regime? Hitotsubashi Journal of Law and Politics, 2016/44, 43-65. 
re vagy környezetre nézve valós vagy potenciális veszélyt jelentő keresőtevékenységek útján környezeti kárt okoztak. ${ }^{34}$ A velük szemben történő fellépés elsődlegesen az illetékes tagállami hatóságok feladata. Ugyanakkor az irányelv tervezete ${ }^{35}$ is tartalmazta már azokat a lehetőségeket, amelyeken keresztül a magánszemélyek is bizonyos jogosítványokhoz jutottak a környezeti felelősség érvényesítése terén. Ennek jelentősége még tovább nőtt azzal, hogy az Európai Bizottság 2003-ban benyújtott, igazságszolgáltatáshoz való hozzáférésre vonatkozó irányelvtervezete a tagállamok ellenállásán később megbukott. ${ }^{36}$

Az irányelv 12. cikke értelmében azok a magánszemélyek (természetes és/ vagy jogi személyek), akiket a környezeti károk nagy valószínűséggel érintenek (kellően érdekeltek vagy jogaik megsértésére hivatkoznak ${ }^{37}$ ), jogosultak közölni az észrevételeiket az illetékes hatósággal, illetve felkérni a hatóságot az irányelv alapján történő eljárásra. Ebből a szempontból egy környezetvédő civil szervezet (az irányelv megfogalmazásában: „a környezetvédelem ügyét támogató és a nemzeti jog előírásainak megfelelő nem kormányzati szervezet") kellően érdekeltnek, illetve jogsérelmet szenvedettnek minősül. Amennyiben az intézkedés iránti kérelem, valamint a magánszemély által benyújtott észrevételek valószínúsítik a környezeti károk fennállását, az illetékes hatóság köteles ezeket megvizsgálni, majd a „lehető leghamarabb és minden esetben" tájékoztatást nyújtani arról, hogy intézkedik-e a kérelem alapján, a döntése okainak megjelölésével. ${ }^{38} \mathrm{Az}$ irányelv 13 . cikke alapján az említett magánszemélyek bírósághoz vagy olyan más, független és pártatlan köztestülethez (public body) fordulhatnak, amely hatáskörrel rendelkezik az illetékes hatóság határozatainak, eljárásainak vagy mulasztásainak az anyagi és eljárásjogi felülvizsgálatára.

\section{A környezetvédő civil szervezetek ügyféli jogállása}

A környezet védelmének általános szabályairól szóló 1995. évi LIII. törvény (a továbbiakban: Kvt.) VIII. fejezete részletesen foglalkozik a nyilvánosság részvételével a környezetvédelemben. A részvétel joga hatósági és nem hatósági eljárásokra is vonatkozik; előbbi esetben nemcsak személyesen vagy képviselő útján, hanem települési önkormányzatokon keresztül, vagy egyesületek révén is gyakorolható. ${ }^{39}$

Amikor a jogalkotó döntést hoz az általános eljárásjogi szabályozás személyi hatályáról, valójában arról dönt, hogy kik jogosultak az eljárás részeivé válva annak lefolyását, és ezen keresztül a végkimenetelét is akár befolyásolni, s melyek azok

\footnotetext{
${ }^{34}$ A környezeti kár fogalmát az irányelv 2. cikkének 1. pontja határozza meg.

${ }^{35}$ Proposal for a Directive of the European Parliament and of the Council on environmental liability with regard to the prevention and remedying of environmental damage, $\operatorname{COM}(2002) 17$ final, HL C 151E, 25/5/2002, 132-145.

${ }^{36}$ PÁNOVIcs Attila: The Need for an EU Directive on Access to Justice in Environmental Matters. Essays of Faculty of Law University of Pécs, Yearbook of 2010, Pécs, 2010, 135-161.

${ }^{37}$ A tagállamok feladata annak meghatározása, hogy mit jelent a kellö érdekeltség és a jogsérelem fogalma.

38 12. cikk (3)-(4).

39 Kvt. $97 . \S(3)$.
} 
az érdekeltek, akik ügyféli jogállás híján csak korlátozott jogosítványokkal rendelkezhetnek. ${ }^{40} \mathrm{Az}$ ügyféli jogállás biztosítása kulcsfontosságú kérdés, hiszen még a legmegalapozottabb jogorvoslati érvek is hatástalanok és értelmetlenek akkor, ha az adott személy vagy szervezet nem tekinthető ügyfélnek, és így gyakorlatilag semmilyen lehetősége nincs az érvei előterjesztésére, nem beszélve az egyéb ügyféli részjogosítványok (pl. iratbetekintési jog) gyakorlásáról. ${ }^{41}$

A Kvt. 98. § (1) bekezdése az 1990-es évek második felétől biztosította az ügyféli jogállást a civil (társadalmi) szervezetek számára környezeti ügyekben. ${ }^{42} \mathrm{~A}$ törvény 2012. január 1-töl hatályos szabályai szerint „a környezetvédelmi közigazgatási hatósági eljárásokban a müködési területükön az ügyfél jogállása” már csak „a környezetvédelmi érdekek képviseletére létrehozott politikai pártnak és érdekképviseletnek nem minősülő, a hatásterületen müködő egyesületeket” illeti meg. ${ }^{43}$ A környezetvédelmi érdekek képviseletére létrehozott alapítványokkal kapcsolatos vita tehát lezárult, a lényeg azonban nem változott: az egyesületeket ex lege megilleti az ügyféli jogállás a közigazgatási hatósági eljárásokban.

Érdemes felidézni, hogy még 2010 októberében képviselői önálló indítványként került benyújtásra a Ket., ${ }^{44}$ valamint egyes kapcsolódó törvények módosítására irányuló törvényjavaslat, amely a civil (társadalmi) szervezetek fellépése által okozott visszaélések elkerülésével, valamint a hatósági eljárások hatékony és gyors lefolytatásával indokolta egy ügyfélhez hasonló jogállás bevezetését. A módosítás nem vonatkozott a jogorvoslati eljárások megindítására irányuló kérelem benyújtására való jogosultságra, viszont nemcsak a Ket. 15. § (5) bekezdését, hanem többek között a Kvt. 98. § (1) bekezdését is érintette volna, nem mellékesen beleütközve az Aarhusi Egyezmény és az uniós jog vonatkozó rendelkezéseibe. De nem Magyarország az egyetlen, ahol a civil szervezetek számára biztosított jogosítványok érvényesülését időről időre szűkíteni próbálja a jogalkotó. ${ }^{45}$

40 Hohmann Balázs: A hatósági eljárás társadalmi ellenőrzésének lehetőségei. Tudatosan a Környezetünkért Egyesület, Pécs, 2018, 19-20.

41 Jogorvoslati jogok Magyarországon. Kézikönyv, EMLA-J\&E, h. n., 2019, 19. A kiadvány elérhető a Client Earth honlapján: https://www.clientearth.org/media/dlrlltzw/2020-01-06-jogorvoslati-jogok-magyarorszagonkezikonyv-ext-hu.pdf (2020. 11. 10.).

42 „Az állampolgárok által a környezetvédelmi érdekeik képviseletére létrehozott egyesületeket és más politikai pártnak, érdekképviseletnek nem minősülő - a hatásterületen müködő - társadalmi szervezeteket (a továbbiakban: szervezet) a környezetvédelmi államigazgatási eljárásokban területükön az ügyfél jogállása illeti meg."

${ }^{43} 98$. § (1); hasonló rendelkezést tartalmaz egyébként a fogyasztóvédelemről szóló 1997. évi CLV. tv. 46. § (2) bekezdés a) pontja, a kereskedelemről szóló 2005. évi CLXIV. tv. 8. § (1) bekezdése, valamint a gazdasági reklámtevékenység alapvető feltételeiről és egyes korlátairól szóló 2008. évi XLVIII. tv. 26. § (2) bekezdése. Érdekesség, hogy 2012. január 1. óta a biztonságos és gazdaságos gyógyszer- és gyógyászati segédeszköz-ellátás, valamint a gyógyszerforgalmazás általános szabályairól szóló 2006. évi XCVIII. tv. 18/A. § (3) bekezdése alapján civil szervezetek minősülnek ügyfélnek az (1)-(2) bekezdések szerinti eljárásokban (amelyek nyilvántartásba vett tevékenysége a betegek jogainak védelmére irányul). Ez utóbbi esetben azonban már a nyilvántartásba vétel értelmezése is problémákat vethet fel.

${ }^{44}$ A közigazgatási hatósági eljárás és szolgáltatás általános szabályairól szóló 2004. évi CXL. törvény, amelyet hatályon kívül helyezett az általános közigazgatási rendtartásról szóló 2016. évi CL. törvény (Ákr.).

${ }^{45}$ Lásd a ClientEarth honlapján az "Access to Justice in Austria: One Step Forward, Two Steps Back" címü bejegyzést (2018. 12. 03.). https://www.clientearth.org/projects/access-to-justice-for-a-greener-europe/updates/access-to-justice-in-austria-one-step-forward-two-steps-back/ (2020. 06. 20.). 
A Kvt. hatályos szabályai alapján, környezetveszélyeztetés, környezetszennyezés vagy környezetkárosítás esetén az egyesület jogosult fellépni a környezet védelme érdekében, és állami szervtöl, helyi önkormányzattól ${ }^{46}$ a megfelelő, hatáskörébe tartozó intézkedést kérni, vagy a környezethasználó ellen pert indítani. ${ }^{47}$ Utóbbi esetben az egyesület ${ }^{48}$ kérheti a bíróságtól, hogy a veszélyeztetőt tiltsa el a jogsértő magatartástól (müködéstől), illetve kötelezze a kár megelőzéséhez szükséges intézkedések megtételére. ${ }^{49}$ Ennek bíróság általi kimondásához polgári per megindítására van szükség.

Gyakorlati értéke csak a jövőben fog kiderülni, de fontos elörelépésnek tủnik, hogy a Polgári Perrendtartás új szabályai lehetővé teszik az emberi tevékenységen vagy mulasztáson alapuló, elöre nem látható környezetterhelés által közvetlenül okozott egészségkárosodásból fakadó igények vagy vagyoni kárigények érvényesítése esetén ún. társult per indítását. ${ }^{50}$ Ennek feltétele a bíróság engedélyén túl, hogy legalább 10 felperes legyen, akiknek a tartalmában azonos (reprezentatív) jogait megalapozó tények érdemben valamennyiük vonatkozásában azonosak legyenek.

\section{A finanszírozás nehézségei}

Az állandó kapacitás- és forráshiány a környezetvédő civil szervezeteknél nehezen feloldható problémákat vet fel a túlzottan egyoldalú - akár állami, akár privát ${ }^{51}$ támogatásokkal kapcsolatban. Egyedülálló, de mindenképpen figyelemre méltó kezdeményezés volt, hogy David Gilmour, a Pink Floyd zenekar vezetője 2019-ben több mint 120 gitárját ajánlotta fel jótékonysági árverésen, és a befolyt összeget (mintegy 21,5 millió dollárt!) a ClientEarth nevű szervezetnek ajánlotta fel, amely arról ismert, hogy kifejezetten jogi eszközökkel lép fel a környezet védelme érdekében, ${ }^{52}$ és számos alkalommal indított peres eljárást az elmúlt években többek között az EU Bírósága előtt is.

Magyarországon 2004-töl, az uniós forrásoknak köszönhetően számos civil szervezet jelentős forrásokhoz jutott, a forráshiány összességében mégis egyre növekedett a szektoron belül, ami az aktivitást elsősorban az elnyert pályázatokban foglalt időszakokra korlátozta. Ez a helyzet gyakran az alapműködés veszélyeztetése miatt

${ }^{46}$ A Magyarország helyi önkormányzatairól szóló 2011. évi CLXXXIX. tv. 3. § (1) bekezdése értelmében a helyi önkormányzás joga a települések (települési önkormányzatok) és a megyék (területi önkormányzatok) választópolgárainak a közösségét illeti meg.

${ }^{47}$ Kvt. 99. § (1); hasonló jogokat biztosít a természet védelméröl szóló 1996. évi LIII. tv. 65. § (1) bekezdése a természetvédelmi célú egyesületek számára a természeti területek és értékek jogellenes károsítása, veszélyeztetése esetén.

${ }^{48}$ Bár a törvény felperes helyett itt még mindig az ügyfél kifejezést használja.

${ }^{49}$ Kvt. 99. § (2).

${ }^{50}$ 2016. évi CXXX. tv. 583. § (2) bekezdés c) pont.

${ }^{51}$ A jelentős környezethasználattal járó tevékenységeket végző, illetve az emberi életet, egészséget veszélyeztető termékeket gyártó cégektől származó támogatások elfogadásáról van itt szó elsősorban.

${ }^{52}$ Lásd a ClientEarth honlapján a "David Gilmour Proceeds from Guitar Auction to ClientEarth" címủ bejegyzést (2019. 06. 19.). https://www.clientearth.org/david-gilmour-to-donate-proceeds-from-guitar-auction-toclientearth/ (2020. 06. 18.). 
végül számos szervezet ellehetetlenüléséhez vezet(ett). 2010-töl azonban a környezet- és természetvédelem még erőteljesebben háttérbe szorult a politikai élet meghatározó szereplőinek a preferenciái között, illetve az állam sokkal erősebb, paternalista tekintélyként jelent meg, ami erősebb kontrollhoz vezetett a civil szervezetek felett is, párhuzamosan egy egészen más típusú (álcivil, pszeudocivil) szervezeti forma megjelenésével. A szakirodalomban ismert, ún. GONGO (Government Organised NGO) kifejezés pont az olyan civil szervezetekre utal, amelyeket a kormányzat hoz létre, finanszíroz és irányítja a működésüket is. Ezeknek a szervezeteknek a célja kizárólag hatalom-technikai jellegű, mert az őket létrehozó kormányzati hatalom legitimálását szolgálja. Bár a tevékenységük lehet hasznos is a társadalom számára, alapvetően mégsem valamiféle változás elérése (például a környezet megörzése és javítása) érdekében tevékenykednek. A finanszírozásuk jellemzően nem átlátható, illetve nem projektalapú, hanem működési támogatás jellegü, elvonva az amúgy is korlátozottan rendelkezésre álló pénzügyi forrásokat a valódi civil szervezetektől. ${ }^{53}$

Emlékezetes a jövő nemzedékek országgyülési biztosának (JNO) még 2011 végén, a Környezeti Tanácsadó Irodák Hálózatának (KÖTHÁLÓ) müködésével és a civil szervezetek ellehetetlenülésével kapcsolatban született állásfoglalása. ${ }^{54}$ Ebben kimondásra került, hogy az államnak a környezet védelme érdekében hatékony szervezeti és intézményrendszert kell kiépítenie, amibe a közigazgatási szervek mellett a civil szervezetek is beletartoznak, akik részben állami feladatokat vállalnak át (elismerten hozzájárulva a Nemzeti Környezetvédelmi Programok - NKP-k megvalósításához). A kiépítésnek és müködtetésnek alapvető feltétele a pénzügyi források biztosítása, a kormányzat azonban még a források szinten tartásához sem biztosította a szükséges összegeket, hanem éppen ellenkezöleg, tendenciaszerüen csökkentette a környezetvédő civil szervezetek számára rendelkezésre álló keretet. Tágabb összefüggésben nézve a probléma nem csak a zöld szektort érintette, de a 2008-as válság után még radikálisabban csökkent az akkoriban még önállóságot élvező környezetvédelmi tárca által biztosított összeg..$^{55}$

Állásfoglalása 22. pontjában a JNO úgy fogalmazott, hogy „,az egészséges környezethez való jog megköveteli egy bizonyos védettségi szint fenntartását az állam részéröl, ebböl adódóan meghatározott mértékü pénzügyi források biztositása is állami kötelesség”. Az Aarhusi Egyezmény követelményeit is figyelembe véve „a civil szervezetek müködését korlátozó jogi és pénzügyi elöírások csökkentése párhuzamosan megköveteli a tevékenység folytatását biztositó és támogató, kedvező jogi és pénzügyi környezet megteremtését. Ennek pedig szerves része a költségvetési forrásokból a müködéshez szükséges alapvető pénzügyi támogatás biztositása, minimális követelményként annak szinten tartása, azonban semmiképpen sem tolerálható annak tendenciaszerü csökkentése". ${ }^{56} \mathrm{~A}$ költségvetési források ilyen radi-

${ }^{53}$ VARga Áron: A GONGO-jelenség és kormányzati civilek Magyarországon. In: Antal Attila (szerk.): A civilek hatalma: a politikai tér visszafoglalása. Noran Libro, Budapest, 2016, 234-248.

${ }^{54}$ A Jövő Nemzedékek Országgyűlési Biztosának állásfoglalása a Környezeti Tanácsadó Irodák Hálózatának működésével kapcsolatosan. Budapest, 2011. november 18. JNO-696-2/2011.

${ }^{55}$ Az éves szinten csaknem 1 milliárdos keretösszeg a válság következtében mintegy 300 millió forintra csökkent, 2012-ben ez is kevesebb mint a felére esett vissza.

${ }^{56}$ Lásd a JNO idézett állásfoglalását, 28. pont. 
kális csökkentése ezért a feladatellátás ellehetetlenülését eredményezheti, ami az ombudsman szerint sérti a társadalmi részvétel elvét és az Alkotmányban/Alaptörvényben biztosított egészséges környezethez való jogot is.

Az Agrárminisztérium tehát minden évben pályázatot hirdet a környezet- és természetvédelmi civil szervezetek számára, a Nemzeti Környezetvédelmi Programok céljainak megvalósítása érdekében. Ennek keretösszege az évek során folyamatosan csökkent; a 2020 januárjában meghirdetett pályázat esetében összesen már csak 70 millió forintnyi támogatásra pályázhattak az egyesülési jogról, a közhasznú jogállásról, valamint a civil szervezetek müködéséről és támogatásáról szóló 2011. évi CLXXV. törvény szerinti közhasznúsági fokozattal rendelkező zöld szervezetek ${ }^{57} \mathrm{~A}$ tárca azonban április végén - hivatkozva a Magyarország 2020. évi központi költségvetésének a veszélyhelyzettel összefüggő eltérő szabályairól szóló 92/2020. (IV. 6.) Korm. rendelet 6. §-ára - tájékoztatta a pályázókat, hogy az előirányzati öszszeg átcsoportositásra került a központi költségvetésbe, aztán később ezt a döntést - indoklás nélkül - megváltoztatták. 58

Ha figyelembe vesszük, hogy a Zöld Forrás pályázatok keretösszege jelentősen csökkent az évek során, a környezetvédő civil szervezetek által választott delegáltak pedig egyre kisebb mértékben vehettek részt a források elosztásában, ez a támogatási forma mostanra szinte jelképes mértéküre zsugorodott (bár még így is sokkal kiszámíthatóbban müködött a rendszeresen támogatott szervezetek számára, mint például a Nemzeti Együttműködési Alap keretében meghirdetett pályázatok). Ahhoz képest pedig, hogy más ágazatok milyen pénzügyi forrásokhoz jutnak a központi költségvetésböl, a környezet- és természetvédelemmel szemben, 2010 óta megfigyelhető ellenérzés itt is tetten érhető volt a kormányzat részéről. Mindeközben az Áder János köztársasági elnök által, 2017 decemberében létrehozott Kék Bolygó Klímavédelmi Alapítvány ${ }^{59}$ - mely ugyanúgy szerepel a civil szervezetek közhiteles névjegyzékében ${ }^{60}$ - milliárdos összegeket kapott müködésre az évek során, ${ }^{61}$ majd a Kormány - az „Alapítvány tevékenységének bővítése és Magyarország környezetés klímavédelmi céljainak elérése érdekében" - 5 milliárd forint nem visszatérítendő támogatást biztosított a Kék Bolygó Klímavédelmi Kockázati Tőkealap részére. ${ }^{62}$

\section{A magánszemélyek lehetőségeit befolyásoló egyéb tényezők}

A továbbiakban a szabályozás két olyan elemére térek ki, amelyek jelentősen befolyásolják a civilek lehetőségeit a környezeti felelősség érvényesítésével össze-

\footnotetext{
${ }^{57}$ https://2015-2019.kormany.hu/hu/foldmuvelesugyi-miniszterium/parlamenti-allamtitkarsag/hirek/megjelent-azold-civil-szervezeteket-tamogato-zold-forras-palyazat-2020-evi-kiirasa (2020. 07. 01.).

${ }^{58}$ A Zöld Forrás pályázatból 2020-ban végül 49 civil szervezet kapott támogatást. Az eredményeket lásd: https://2015-2019.kormany.hu/hu/foldmuvelesugyi-miniszterium/parlamenti-allamtitkarsag/hirek/a-2020-evizold-forras-palyazat-eredmenye (2020. 08. 26.).

59 Lásd a Kék Bolygó Klímavédelmi Alapítvány honlapját: https://kbka.org/kik-vagyunk/ (2020. 07. 09.).

${ }^{60}$ A szervezet nyilvántartási száma: 01-01-0012358.

61 1507/2018. (X. 15.) Korm. határozat a Kék Bolygó Klímavédelmi Alapítvány támogatásáról.

62 1260/2020. (V. 27.) Korm. határozat a Kék Bolygó Klímavédelmi Kockázati Tőkealapról.
} 
függésben. Ezek közül negatív példaként említhető a közigazgatási döntések ellen igénybe vehető eszközöket az anyagi jogerő mielőbbi beálltához igazító jogorvoslati rendszer kialakítása Magyarországon, egyértelmúen jó irányba tett lépés viszont a visszaéléseket bejelentő személyeket érintő szabályozás fejlődése.

\subsection{A kétfokú közigazgatási eljárás megszüntetése}

Az Alaptörvény XXVIII. cikk (7) bekezdése szerint mindenkinek joga van ahhoz, hogy jogorvoslattal éljen az olyan bírósági, hatósági és más közigazgatási döntés ellen, amely a jogát vagy jogos érdekét sérti. A jogorvoslathoz való jog biztosítása szempontjából a kétfokú közigazgatási eljárás nem követelmény, a hatékony jogvédelemhez az is elegendő, ha az egyfokú eljárásban meghozott döntést rögtön a bírósághoz fordulás lehetősége követi. A környezetvédő civil szervezetek lehetőségeit mégis tovább szűkítette, hogy a szervezetrendszer átalakítását 2019-ben az eljárási szabályozás megújitása követte egy újabb salátatörvény formájában. ${ }^{63}$

Ennek értelmében 2020. március 1-től számos hatósági eljárásban - beleértve a környezet- és természetvédelmi ügyeket is - megszünt a közigazgatási határozatok elleni fellebbezési lehetőség, jogorvoslatként kizárólag közigazgatási peres eljárást lehet kezdeményezni, amely „, jogállamiság elvének inkább megfelelö, közigazgatási szervezeten kívüli eljárási típus". ${ }^{44}$ A jogalkotó célja a közigazgatási bírósági rendszer kiteljesitése volt, a végleges, már nem támadható döntéshez (a bírói döntéssel létrejövő anyagi jogeröhöz) füződő érdekek mielőbbi érvényesítése érdekében. A fellebbezési jog megszüntetésével azonban jelentősen szükült az ügyfelek jogorvoslati joga, mivel megszünt egy felülvizsgálati lehetőség, gyakorlatilag csak a bírósági út maradt, ami több szempontból is megnehezíti az ügyfelek helyzetét.

Nemcsak arról van szó, hogy a keresetlevél benyújtásának szigorú formai és tartalmi követelményei vannak, hanem a költség- és időtényező is jelentősen eltér, nemcsak a perek elhúzódása, hanem a gyakran felmerülő szakértői bizonyítás szükségessége miatt. A közigazgatási hatósági eljárások ugyanis jellemzően sokkal kevésbé költségigényesek, és időben is jelentősen rövidebbek, mint a bírósági procedúrák. ${ }^{65}$ Környezet- és természetvédelmi ügyekben az sem mellékes, hogy a fellebbezések elbírálása esetén adott ügytípusok kerültek a témában jártas közigazgatási szakemberek elé, míg a közigazgatási perek esetén a specializáció ilyen mértékben nem érvényesül. Márpedig a környezet- és természetvédelmi ügyek esetében az időtényezőnek gyakran döntő szerepe van az ügy kimenetelében, de ez nem azt jelentette korábban sem, hogy a környezetvédő civil szervezetek minden rendelkezésre álló jogorvoslati eszközt igénybe vettek volna. A bírósághoz fordulásra mindig is csak kivételesen került sor, mert a fellebbezés lehetővé tette a másodfokon eljáró közigazgatási szerv számára a környezeti érdekek megfelelő figyelembevételét.

${ }^{63}$ 2019. évi CXXVII. törvény az egyes törvényeknek az egyfokú járási hivatali eljárások megteremtésével összefüggő módosításáról.

${ }^{64}$ T/12233. számú törvényjavaslat az általános közigazgatási rendtartásról. Budapest, 2016. szeptember, 105. (https://www.parlament.hu/irom40/12233/12233.pdf).

${ }^{65}$ RozSNYAI Krisztina: Ügyféli jogosultságok a hatósági eljárásban - több vagy kevesebb? Közjogi Szemle, 2020/2, 13. 
Természetesen az sem mindegy, hogy hol kerül sor a jogorvoslati eljárás lefolytatására. A közigazgatási és munkaügyi bíróságok megszünésével a közigazgatási jogvitákban eljáró bíróságok hatásköre és illetékessége is változott; 2020. április 1-töl nyolc törvényszék jár el a közigazgatási perekben első fokon, regionális illetékességgel. ${ }^{66} \mathrm{Az}$ illetékes bíróság távol eshet a felperes civil szervezet székhelyétől, ami még tovább növelheti a felmerülő költségeket. Továbbá azt se felejtsük el, hogy a Ptk. a szerződéses károkozás terén felerősítette a jogi személy vezető tisztségviselőinek a felelősségét, akik az egyesület jogutód nélküli megszünése esetén a gazdálkodó szervezetek vezetőihez hasonlóan felelnek a kielégítetlen hitelezői követelésekért. ${ }^{67}$ Ez könnyen csapdahelyzetet teremthet a sokszor állami forrásokból gazdálkodó civil szervezeteknél, illetve a költséges szakértői közremüködést igénylő perek esetén.

\subsection{A visszaéléseket bejelentő személyek védelme}

Az Alaptörvény XXV. cikke értelmében mindenkinek joga van ahhoz, hogy egyedül vagy másokkal együtt, írásban kérelemmel, panasszal vagy javaslattal forduljon bármely közhatalmat gyakorló szervhez. Ez a petíciós jog tartalmilag két fogalmi elemmel bír: a kérelem, panasz vagy javaslat benyújtása mellett magában foglalja a megkeresett szerv válaszadását is, amely köteles foglalkozni az adott üggyel. ${ }^{68}$ A Kvt. is biztosítja mindenki számára a jogot, hogy a környezet veszélyeztetése, károsítása vagy szennyezése esetén a környezethasználó és a hatóságok figyelmét erre felhívja, a hatáskörrel rendelkező szerv pedig határidőn belül érdemi választ köteles adni az írásban tett felhívásra (természetesen a szükséges intézkedés megtétele mellett). ${ }^{69}$

A gyakorlatban azonban a jogsértéseket, visszaéléseket jelző személyek védelmét garantálni kell, mert ha a jogellenes tevékenységet végző személyekkel kapcsolatban bejelentést tevő személy (whistleblower) nem érzi biztonságosnak a birtokában lévő információk megosztását, a közérdek - és ide tartozik a környezet védelme is - szempontjából súlyos jogsértések maradhatnak titokban, lehetetlenné válik a károk megelőzése, illetve elmaradhat a károkozók felelősségre vonása. Az Európai Parlament a környezeti felelősségről szóló irányelv végrehajtásáról szóló, 2017. október 26-i állásfoglalásában ${ }^{70}$ felhívta a figyelmet rá, hogy az átültetés nehézségei között okként jelenik meg egy szabványosított eljárás hiánya, amelynek keretében a környezeti kár közvetlen veszélyéröl vagy a bekövetkezett kárról értesíteni lehetne az illetékes hatóságot. ${ }^{71}$ Ezért javaslatként szerepelt az állásfoglalásban

\footnotetext{
${ }^{66}$ Fővárosi Törvényszék, Budapest Környéki Törvényszék, Debreceni Törvényszék, Győri Törvényszék, Miskolci Törvényszék, Pécsi Törvényszék, Szegedi Törvényszék, Veszprémi Törvényszék.

${ }^{67}$ Ptk. 3:86. § (1)-(2).

${ }^{68}$ Lásd az alapvető jogok biztosának jelentését az AJB-3633/2016. számú ügyben, Budapest, 2016. szeptember.

${ }^{69}$ Kvt. 97. § (2).

${ }^{70}$ Az Európai Parlament 2017. október 26-i állásfoglalása a környezeti károk megelőzése és felszámolása tekintetében a környezeti felelősségről szóló, 2004. április 21-i 2004/35/EK európai parlamenti és tanácsi irányelv (környezeti felelősségről szóló irányelv) alkalmazásáról (2016/2251(INI)). P8_TA(2017)0414.

${ }^{71}$ Lásd az állásfoglalás 21. pontját.
} 
olyan csatorna létrehozása is, amelyen keresztül a környezetvédő NGO-k és egyéb érdekelt testületek előterjeszthetik észrevételeiket és kritikai megjegyzéseiket.

Az Európai Bizottság 2018-ban olyan minimumszabályok elfogadására tett javaslatot, amelyek a közérdek védelme érdekében kiküszöbölik a széttagolt uniós szabályozásból fakadó problémákat, erős és magas szintű védelmet biztosítanak a visszaéléseket bejelentő személyek számára. Ennek alapján került elfogadásra az uniós jog megsértését bejelentő személyek védelméről szóló irányelv (2019. október 23.). ${ }^{72} \mathrm{Az}$ irányelv átültetésének végső határideje 2021. december 17.

Az irányelv rendelkezéseit alapvetően olyan, a magánszektorban vagy a közszférában dolgozó személyekre kell alkalmazni, akiknek munkavégzéssel összefüggésben jutott tudomására a jogsértésre vonatkozó információ, de a védelem a velük kapcsolatban álló harmadik személyekre is kiterjed. A bejelentő maga dönthet arról, hogy névtelenül, illetve belső vagy külső csatornákon keresztül osztja meg az információkat azokkal a személyekkel, akik jogosultak a bejelentések fogadására. Az irányelv előírja nyilvántartás vezetését valamennyi bejelentésről, illetve a bejelentések tárolását, ameddig az szükséges és arányos. Az illetékes hatóságoknak a bejelentések vizsgálatának teljes ideje alatt garantálniuk kell a bejelentők személyazonosságának védelmét, továbbá a tagállamoknak hatékony, arányos és visszatartó erejű szankciókat kell kidolgozniuk azokkal a magánszemélyekkel szemben, akik akadályozzák a bejelentést, megtorlást (például kényszerítést, megfélemlítést) alkalmaznak, vagy zaklatásszerü eljárást indítanak a bejelentővel szemben.

\section{Záró gondolatok}

A Központi Statisztikai Hivatal (KSH) adatai szerint 2018-ban körülbelül 61000 nonprofit szervezet müködött Magyarországon. Ebböl mintegy 34000 egyesületi, 20000 pedig alapítványi formában tevékenykedett (a többi nonprofit jellegű szervezet nem tekinthető klasszikus civil szervezetnek). A legtöbb civil szervezet hagyományosan kulturális, sport és szabadidős, illetve oktatási célokkal müködik, illetve a civil szektor kapacitásait tekintve nagy különbségek vannak az intézményesültebb városi, valamint a kisebb, vidéki szervezetek között. A szervezeti tagság fokozatos elöregedése mellett meglehetősen gyengék a társadalmi bázis kiépítésére irányuló erőfeszítések, jellemzően hiányoznak a kapacitások bővítéséhez szükséges erőforrások, továbbá állandó a szakemberhiány, ami részben a stabil finanszírozás hiányából fakad. Professzionális munkaerőt csak az erősebb szervezetek tudnak foglalkoztatni, a legtöbb civil szervezet nagyon kis stábbal (önkéntesekkel és/vagy 1-2 alkalmazottal) müködik, és nem rendelkeznek belső struktúrával, miközben a hazai jogszabályok viszonylag magas szintü átláthatóságot követelnek meg minden civil szervezettől, beleértve az éves jelentések közzétételét is.

A társadalmi részvétel visszaszorulása - paradox módon - az állam visszaszorulásával is összefüggésben van, ti. a kormányzatok az elmúlt évtizedekben túlsá-

72 Az Európai Parlament és a Tanács (EU) 2019/1937 irányelve (2019. október 23.) az uniós jog megsértését bejelentő személyek védelméről. HL L 305, 26/11/2019, 17-56. 
gosan gyakran gyengítették saját magukat - és erősítették a befektetők és a nagy társaságok erejét - a deregulációt, illetve a kereskedelmi és pénzügyi liberalizációt szolgáló politikák elfogadásával. ${ }^{73}$ Mindez fenntarthatatlan globális egyenlőtlenségekhez vezetett, amelyek ékes példája volt a 2008 októberében kirobbant pénzügyi és gazdasági világválság, valamint az azóta eltelt időszak fejleményei. A nemzetközi hálózatokhoz és az Európai Unióhoz történő csatlakozás, valamint az említett krízis jelentősen átrendezte és átalakította a civil szektor lehetőségeit is, részben szélesítve, ugyanakkor jelentősen szükítve is a környezetvédő szervezetek mozgásterét. ${ }^{74}$

A társadalmi részvétel a környezetet érintő, különféle döntések meghozatalában jelenleg csak bizonyos engedélyezési eljárások (pl. a környezeti hatásvizsgálati eljárások) esetén tekinthető kielégítően szabályozottnak. Tervek, stratégiák és koncepciók, illetve a környezetvédelmi jogszabályok elfogadása során ez a lehetőség annál hatékonyabb, minél korábbi fázisban van lehetőség a nyilvánosság bekapcsolódására. Ennek hiányában a részvételi lehetőség inkább csak papírtigrisként értelmezhető. ${ }^{75}$ Pedig a civil szervezetek a jelenleginél sokkal hatékonyabban élhetnének a környezeti felelősség hatékonyabb érvényesítése érdekében is, például kampányt indíthatnának a jogszabályi előírások szigorításáért, a környezetkárosítók elleni küzdelem hatékonyabbá tételéért, a büntetési tételek emeléséért, vagy a felelősség alóli mentesülés feltételeinek szükítéséért.

Zárásként megemlítendő, hogy a környezeti felelősség érvényesítésével kapcsolatban egyre több országban jutnak szerephez az ún. klímaperek, amelyek legfőbb funkciója jelenleg az üvegházhatású gázok csökkentése terén vonakodó döntéshozók rákényszerítése érdemi mitigációs törekvések megtételére. ${ }^{76} \mathrm{~A}$ klímakárok megtérítésére irányuló esetek elbírálása során a bíróságok (és egyéb szervek) komoly dogmatikai problémákkal szembesülnek, amelyek megoldása egyre sürgetőbb kihívást jelent a jövőre nézve.

${ }^{73}$ No Future Without Justice, Development Dialogue, Report of the Civil Society Reflection Group on Global Development Perspectives. Dag Hammarskjöld Foundation, No. 59, June 2012, 79. https://www.daghammarskjold.se/publication/future-without-justice/ (2020. 11. 20.).

${ }^{74}$ GLIED Viktor: A halványtól a mélyzöldig, A globális környezetvédelmi mozgalom negyed százada. IDResearch/ Publikon, Pécs, 2016, 138.

75 Peeters, Marjan-Eliantonio, Maria: On Regulatory Power, Compliance, and the Role of the Court of Justice in EU Environmental Law. In: Peeters, Marjan-Eliantonio, Maria (szerk.): Research Handbook on EU Environmental Law. Edward Elgar, 2020, 488.

${ }^{76}$ SulYOK Katalin: A klímaperek kihívásai és sikerei - Az Urgenda-ítélet tanulságai. Közjogi Szemle, 2020/1, 6. 